\title{
Pengaruh Teknik Restrukturing Kognitif Dalam Konseling Kelompok Terhadap Prokrastinasi Akademik Mahasiswa Bimbingan Dan Konseling UNIPA Surabaya Di Masa Pandemi Covid-19
}

\author{
Dimas Ardika Miftah Farid \\ Bimbingan dan Konseling, Universitas PGRI Adi Buana Surabaya, Indonesia \\ dimas.ardika@unipasby.ac.id
}

\begin{tabular}{|c|c|}
\hline i Artikel & Abstrak \\
\hline $\begin{array}{l}\text { Kata kunci: } \\
\text { Restrukturing } \\
\text { Kognitif, } \\
\text { Konseling } \\
\text { Kelompok, } \\
\text { Prokrastinasi } \\
\text { Akademik }\end{array}$ & $\begin{array}{l}\text { Penelitian ini bertujuan untuk mengetahui pengaruh teknik restrukturing kognitif } \\
\text { dalam konseling kelompok terhadap prokrastinasi akademik mahasiswa bimbingan dan } \\
\text { konseling Unipa Surabaya di masa pandemic covid-19. Desain penelitian yang } \\
\text { digunakan adalah studi Pra-Eksperimental dengan One Group Pretest-Posttest Design. } \\
\text { Subjek penelitian ini berjumlah } 6 \text { mahasiswa yang mengalami prokrastinasi akademik } \\
\text { sebagai sampel penelitian yang diambil secara purposive sampling. Data penelitian ini } \\
\text { dianalisis menggunakan SPSS untuk Windows versi 25.0. Berdasarkan hasil uji } \\
\text { Wilcoxon pada tabel diatas diperoleh Asymp. Sig (2-tailed) adalah 0.005. nilai } 0.005 \\
\text { lebih kecil dari <0.05, dikatakan hipotesis Ha diterima, maka dapat disimpulkan bahwa } \\
\text { teknik restrukturing kognitif dalam konseling kelompok berpengaruh terhadap } \\
\text { prokrastinasi akademik mahasiswa bimbingan dan konseling Unipa Surabaya. }\end{array}$ \\
\hline Diterima: & the \\
\hline $\begin{array}{l}11-02-2021 \\
\text { Disetujui: } \\
22-02-2021 \\
\text { Dipubikasik } \\
26-02-2021\end{array}$ & $\begin{array}{l}\text { This study aims to determine the effect of cognitive restructuring techniques in group } \\
\text { counseling on academic procrastination of Unipa Surabaya guidance and counseling } \\
\text { students during the Covid-19 pandemic. The research design used was a pre- } \\
\text { experimental study with One Group Pretest-Posttest Design. The subjects of this } \\
\text { study were } 6 \text { students who experienced academic procrastination as the research } \\
\text { sample taken by purposive sampling. The research data were analyzed using SPSS for } \\
\text { Windows version } 25.0 \text {. Based on the Wilcoxon test results in the table above obtained } \\
\text { Asymp. The Sig ( } 2 \text {-tailed) is } 0.005 \text {. The value of } 0.005 \text { is smaller than }<0.05 \text {, it is said } \\
\text { that the Ha hypothesis is accepted, it can be concluded that cognitive restructuring } \\
\text { techniques in group counseling affect academic procrastination of Unipa Surabaya } \\
\text { guidance and counseling students. }\end{array}$ \\
\hline
\end{tabular}




\section{PENDAHULUAN}

Pembelajaran ditengah pandemi covid-19 memanglah berbeda dengan pembelajaran sebelumsebelumnya. Pembelajaran ditengah pandemi covid-19 harus dilaksanakan secara daring atau online. Untari (2020) menyatakan bahwa munculnya perubahan-perubahan dalam pendidikan merupakan suatu kewajaran, karena kebijakan baru dapat menjadi suatu metode yang relevan dengan kondisi covid-19 saat ini. Tujuan dari pelaksanaan pembelajaran secara daring adalah untuk memutus rantai penyebaran covid-19, dengan begitu mau tidak mau mahasiswa harus belajar dari rumah. Pembelajaran daring (online) ditengah pandemi Covid-19 banyak memunculkan masalah dimasyarakat. Permasalahan yang muncul dalam dunia pendidikan yaitu motivasi belajar mahasiswa menurun, menunda mengerjakan tugas yang diberikan oleh dosen.

Pada masa pandemi covid-19, pembelajaran daring diterapkan di Indonesia. Hal itu berdampak pada mahasiswa yang merasa bosan, jenuh, dengan situasi yang ada di rumah, mereka menginginkan kegiatan di kampus ataupun kegiatan berkumpul dengan teman-temannya. Saat pandemi covid-19 ini menyebabkan mahasiswa merasa malas untuk mengerjakan tugas akademik dari dosen. Itu adalah beberapa pemicu prokrastinasi akademik. Hal itu di dukung dengan penelitian yang dilaksanakan oleh Prawitasari (dalam (Saman, 2017), yang menemukan bahwa ada 83\% wisudawan terlambat dalam penyelesaian skripsi. Edu (2018) berpendapat bahwa belajar yang didorong karena motivasi intrinsik lebih sukses daripada didorong oleh motivasi ekstrinsik.

Prokrastinasi akademik adalah kebiasaan untuk menunda sebuah kegiatan yang berefek buruk di bidang akademik, dalam hal ini penundaan mahasiswa yang dalam mengerjakan tugas yang diberikan oleh dosen. Disfunctional Procrastination yaitu menunda-nunda mengerjakan tugas tanpa ada tujuan jelas, dapat berakibat buruk bahkan menimbulkan masalah. Ghufron (dalam Ghufron \& Risnawita, 2011: 153) menyatakan bahwa prokrastinasi akademik merupakan suatu penundaan yang disengaja dan dilaksanakan dengan berulang kali di bidang akademik.

Berdasarkan wawancara awal dengan dosen pengampu mahasiswa 2019, didapatkan beberapa gejala ini bercirikan sebagai berikut: (1) Melewati batas deadline pengumpulan PR atau tugas, (2) ketidaksesuaian antara rencana yang disusun dengan pengaplikasiannya, (3) rasa tertekan saat menunda tugas/tekanan emosional, (4) persepsi terhadap kemampuan yang dirasakan yaitu merasa takut gagal menyebabkan bahwa mahasiswa ini menyalahkan dirinya bahwa dia merasa tidak mampu.

Schraw, Wadkins \& Olafson (2007) berpendapat bahwa ada beberapa faktor penyebab prokrastinasi akademik, bisa karena pemikiran yang irasional, misalnya "Besok bisa saya kerjakan" "Tenang, masih ada banyak waktu" bisa juga menunda karena hanya ingin melakukan hal yang menyenangkan daripada mengerjakan tugas, misalnya "Main ke Mall lebih menyenangkan daripada mengerjakan tugas saat ini" Faktor-faktor tersebut bisa dipengaruhi karena motivasi belajar mahasiswa baik secara internal maupun eksternal. Mahasiswa juga terkadang merasa kurang percaya diri ketika mengerjakan tugasnya, bimbingan pribadi bisa dilaksanakan sebagai peningkatan kepercayaan diri (Rafikayati, Badiah and Soedarmadji, 2018). 
Peneliti memiliki keyakinan bahwa teknik restrukturing kognitif dalam konseling kelompok akan sangat efektif dan berpengaruh. Konseling kelompok merupakan layanan bimbingan dan konseling yang diberikan oleh seorang konselor kepada konseli dengan tujuan dapat mengembangkan kepribadian, minat dan bakatnya ke arah lebih baik (Hartono dan Soedarmadji, 2012). Layanan konseling kelompok bertujuan untuk menyembuhkan. Dalam pelaksanaan layanan konseling kelompok ini dimodifikasi, yakni dilaksanakan melalui daring, yakni dengan bantuan aplikasi google meet karena pandemik covid-19.

Konseli dilatih untuk memiliki persepsi baru dalam menghadapi permasalahan yang dihadapi, dalam hal ini permasalahan dalam prokrastinasi akademik. Jannah, Suranata dan Suarni (2019) berpendapat bahwa teknik restrukturing kognitif adalah suatu cara konselor dalam membantu konseli dalam meretrukturisasi Kembali pikiran-pikiran yang irasional menjadi pikiran yang rasional. Menurut Cormier, Nurius, \& Osborn (2009), strategi restrukturing kognitif merupakan strategi dalam melatih konseli untuk mengidentifikasi pemikiran yang irasional dan diubah menjadi pikiran yang rasional, serta meningkatkan diri untuk mulai berpikir rasional.

Berdasarkan fenomena di atas, maka peneliti ingin menguji apakah teknik restrukturing kognitif dalam konseling kelompok berpengaruh terhadap prokrastinasi akademik mahasiswa bimbingan dan konseling Unipa surabaya di masa pandemi covid-19.

\section{METODE}

Rancangan penelitian ini menggunakan one group pre-test post-test design yang merupakan penelitian praeksperimental (Sumadi Suryabrata, 2014). Metode kuantitatif dengan one group pretest posttest design (pretes postes dengan satu kelompok) yaitu penelitian satu kelompok saja tanpa kelompok perbandingan. Pretest dilakukan sebelum diberikan perlakuan dan posttest dilakukan setelah perlakuan, perbedaan pretest diasumsikan merupakan efek dari adanya perlakuan. Adapun desain penelitian yang digunakan seperti yang ditunjukkan pada gambar 1 (Sugiyono, 2017). Rancangan penelitian dapat digambarkan sebagai berikut:

\begin{tabular}{|ll|}
\hline $\mathbf{O}_{1}$ & $\mathrm{X}$ \\
\hline
\end{tabular}

Gambar 1. Rancangan Penelitian

Keterangan:

O1 = Nilai pretest (prokrastinasi akademi mahasiswa sebelum diberi treatment)

$\mathrm{X}=$ Treatment (Pemberian treatment teknik restrukturing kognitif dalam konseling kelompok)

$\mathrm{O} 2$ = Nilai post-test (prokrastinasi akademi mahasiswa setelah diberi treatment) 
Penelitian ini menggunakan populasi mahasiswa bimbingan dan konseling Angkatan 2019. Setelah dilakukan pengukuran awal (pretest), mahasiswa yang terindikasi melakukan prokrastinasi akademik akan dilaksanakan layanan konseling kelompok dengan teknik restrukturing kognitif (Pragholapati, 2020). Penelitian ini sebanyak menggunakan sampel 6 mahasiswa. teknik purposive sampling digunakan dalam penelitian ini. Variabel penelitian terdiri dari variabel $\mathrm{X}$ atau variabel bebas dalam penelitian ini yaitu layanan konseling kelompok dengan strategi restrukturing kognitif sedangkan variabel $\mathrm{Y}$ atau variabel terikat yaitu prokrastinasi akademik disfungsional.

Penelitian ini menggunakan skala pengukuran skala likert (likert scale). Teknik pengumpulan data menggunakan validitas dan reliabilitas, uji validitas pada skala pemahaman karier mahasiswa memperoleh 25 item pernyataan yang memenuhi syarat dari 35 item yang telah diuji cobakan. Uji reabilitas yang digunakan dalam peneliian ini menggunakan rumus Alpha Cronbach yang mendapatan hasil 0.824. Data penelitian ini dianalisis dengan uji wilcoxon mendapatkan hasil asymp.sig (2-tailed) yaitu 0.039, sehingga di katakan signifikan.

\section{HASIL DAN PEMBAHASAN}

\section{Hasil Penelitian}

Terdapat tiga kategori rentangan skor dalam skala pengukuran prokrastinasi akademik mahasiswa bimbingan dan konseling Unipa Surabaya, yaitu kategori tinggi, sedang, dan rendah. Melalui ketegori penilaian tersebut diambil 6 mahasiswa dengan kategori tinggi dalam prokrastinasi akademik. 6 mahasiswa yang masuk dalam kategori tinggi dalam prokrastinasi akademik ini diberikan pretest terlebih dahulu, kemudian diberikan treatment yaitu dengan teknik restrukturing kognitif dalam konseling kelompok, dan terakhir akan diberikan posttest untuk mengetahui adakah perubahannya. Rincian hasil pre-test dan post-test dapat diuraikan pada tabel 1 sebagai berikut.

Tabel 1. Perbandingan Skor Pretest dan Post-test

\begin{tabular}{cccccc}
\hline Responden & Pretest & Kategori & Post-test & Kategori & $\begin{array}{c}\text { Tingkat } \\
\text { Perubahan }\end{array}$ \\
\hline RR & 86 & Tinggi & 66 & Sedang & 20 \\
\hline FG & 86 & Tinggi & 65 & Sedang & 21 \\
\hline MA & 94 & Tinggi & 74 & Sedang & 20 \\
\hline JM & 86 & Tinggi & 66 & Sedang & 20 \\
\hline MH & 93 & Tinggi & 74 & Sedang & 19 \\
\hline AB & 85 & Tinggi & 70 & Sedang & 15 \\
\hline
\end{tabular}

Pada tabel 1. diatas menunjukkan setiap responden mengalami penurunan skor dari yang awalnya memiliki prokrastinasi tinggi menjadi sedang. Terjadi penurunan mean score variabel prokrastinasi akademik mahasiswa dalam posttest setelah dilakukan pemberian treatment dengan teknik restrukturing kognitif dalam konseling kelompok. Mean score variabel prokrastinasi akademik mahasiswa saat pretest adalah 88.3 sedangkan mean score variabel prokrastinasi akademik mahasiswa saat posttest adalah 69.1. Terjadi penurunan mean score variabel prokrastinasi akademik mahasiswa sebanyak 19.2\%. 
Statistik non parametrik digunakan dalam penelitian ini dan diuji menggunakan uji Wilcoxon dengan bantuan aplikasi SPSS for Windows versi 25.0. hasil uji Wilcoxon tertera pada tabel 2 dibawah ini.

Tabel 2. Hasil Uji Wilcoxon

\begin{tabular}{lc}
\hline & postest - pretest \\
\hline $\mathrm{Z}$ & $-2,810^{\mathrm{b}}$ \\
\hline Asymp. Sig. (2-tailed) &, 005 \\
\hline
\end{tabular}

a. Wilcoxon Signed Ranks Test

b. Based on positive ranks.

Dasar pengambilan keputusan berdasarkan:

a) Jika nilai asymp. Sig $(2$-tailed $)<0.05$, dinyatakan hipotesis Ha diterima.

b) Jika nilai asymp. Sig (2-tailed) $>0.05$, dinyatakan hipotesis Ha ditolak.

Berdasarkan hasil uji Wilcoxon pada tabel diatas diperoleh Asymp. Sig (2-tailed) adalah 0.005. Nilai 0.005 lebih kecil dari $<0.05$, dikatakan hipotesis Ha diterima.

\section{Pembahasan}

Hasil pelaksanaan penelitian terhadap mahasiswa bimbingan dan konseling Unipa Surabaya ini menunjukkan hasil bahwa teknik restrukturing kognitif dalam konseling kelompok berpengaruh terhadap penurunan prokrastinasi akademik. Hasil penelitian ditunjukkan melalui gambar 2. berikut.

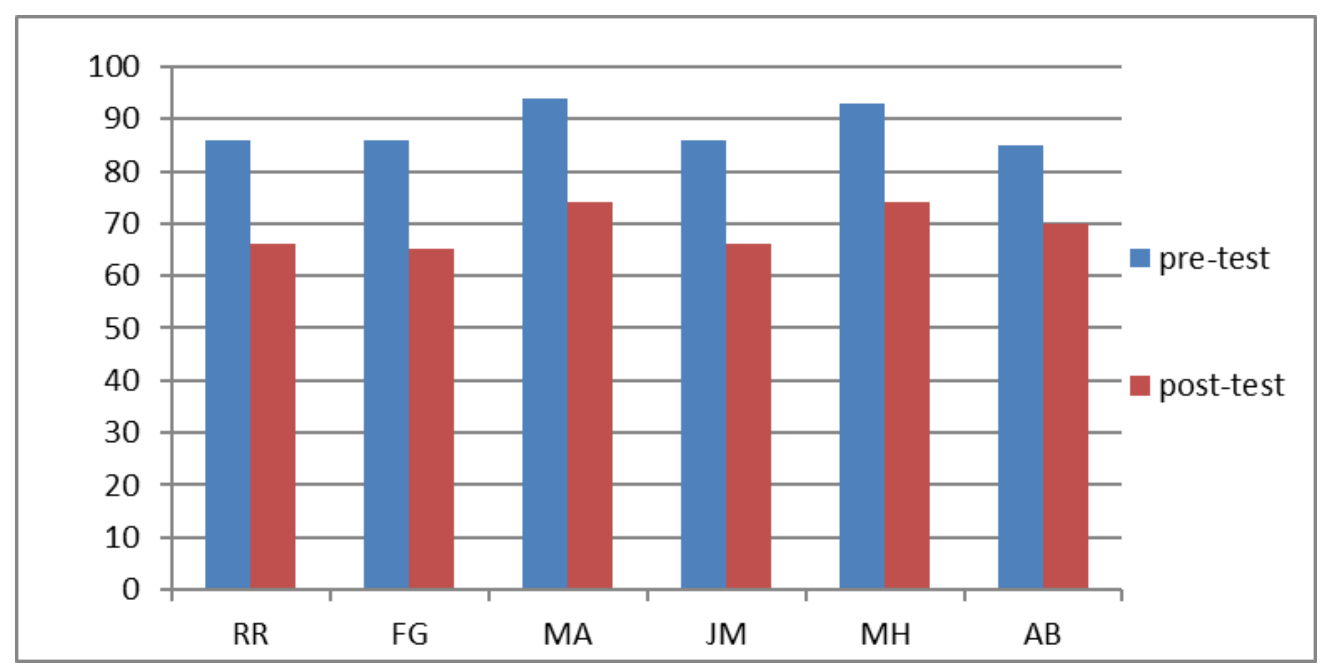

Gambar 2. Perbandingan mahasiswa yang melakukan prokrastinasi akademik ketika pretest dan post-test

Berdasarkan gambar 2., maka dapat diuraikan bahwa maka secara jelas bahwa terdapat penurunan prokrastinasi akademik mahasiswa Bimbingan dan Konseling Unipa Surabaya sebelum diberikan treatment teknik restrukturing kognitif dalam konseling kelompok dan setelah diberikan treatment teknik restrukturing kognitif dalam konseling kelompok. Berdasarkan skor hasil pretest dan posttest terjadi penurunan skor, penurunan skor prokrastinasi akademik. 
Konseli RR mendapatkan presentase skor pretest sebesar 86, kemudian diberikan treatment menggunakan teknik restructuring kognitif dalam konseling kelompok menurunkan tingkat prokrastinasi akademik menjadi 66 berdasarkan hasil posttest. Di diawal pertemuan, konseli RR masih bingung cara mengubah perilaku prokrastinasi akademik yang dilakukannya. Konseli RR pada awal pertemuan cenderung kurang memahami dirinya, sulit mengatur waktu atau jadwal dalam belajar dan mengerjakan tugasnya sehingga mengalami prokrastinasi atau penundaan mengenai tugas akademik yang sangat tinggi. Namun beberapa kali pertemuan konseling, selanjutnya hingga pertemuan terakhir konseli RR sudah mampu mengurangi perilaku prokrastinasi akademiknya. Konseli ini termasuk yang paling aktif saat melakukan proses konseling, konseli menceritakan sikap dan perilakunya dalam hal penundaan tugas-tugas yang konseli dapat dari dosennya. Konseli sudah tau apa yang harus konseli lakukan dalam mengatur jadwal untuk belajar.

Konseli FG mendapatkan presentase skor pretest sebesar 86, kemudian diberikan treatment menggunakan teknik restructuring kognitif dalam konseling kelompok menurunkan tingkat prokrastinasi akademik menjadi 65 berdasarkan hasil posttest. Konseli FG adalah mahasiswa yang lebih suka bermain game online atas ajakan teman-temannya. Konseli FG beranggapan bahwa jika tidak mengikuti temantemannya untuk bermain game online, maka ia merasa ketinggalan teman-temannya. Namun sekarang konseli sudah mampu dan mengetahui bagaimana cara mengurangi perilaku prokrastinasi yang konseli FG alami. Konseli mampu mengurangi waktunya untuk bermain game online dan mampu mengatur waktu untuk mengerjakan tugas akademiknya.

Konseli MA mendapatkan presentase skor pretest sebesar 94, kemudian diberikan treatment menggunakan teknik restructuring kognitif dalam konseling kelompok menurunkan tingkat prokrastinasi akademik menjadi 74 berdasarkan hasil posttest. Konseli MA adalah mahasiswa yang mengalami perilaku prokrastinasi akademik yang paling tinggi karena konseli MA memiliki pemikiran irasional, bahwa "lebih baik mengerjakan tugasnya nanti daripada sekarang, karena masih ada waktu". Itulah yang menjadi kebiasaan konseli. Awalnya konseli beranggapan bahwa menunda mengerjakan tugas itu bukan merupakan suatu masalah, sehingga membuat konseli MA mengalami proktastinasi yang tinggi. Konseli ini juga saat melakukan proses konseling tidak konsentrasi dan lebih suka membuat hal-hal yang menurutnya itu sangat menyenangkan (kurang fokus). Namun, pada akhirnya setelah mengikuti proses konseling kelompok, konseli MA dapat mengurangi perilaku prokrastinasinya

Konseli JM mendapatkan presentase skor pretest sebesar 86, kemudian diberikan treatment menggunakan teknik restructuring kognitif dalam konseling kelompok menurunkan tingkat prokrastinasi akademik menjadi 66 berdasarkan hasil posttest. Konseli JM adalah mahasiswa yang ketika mengikuti proses konseling kelompok beberapa kali terlambat datang. Faktor yang menyebabkan penundaan pengumpulan tugas yaitu lebih mementingkan nonton Drama Korea (Drakor) daripada mengerjakan tugasnya. Namun, 
pada akhirnya setelah mengikuti proses konseling kelompok, konseli JM dapat mengurangi perilaku prokrastinasinya dan sudah bisa memulai menentukan prioritas kewajiban yang harus dilaksanakan.

Konseli MH mendapatkan presentase skor pretest sebesar 93, kemudian diberikan treatment menggunakan teknik restructuring kognitif dalam konseling kelompok menurunkan tingkat prokrastinasi akademik menjadi 74 berdasarkan hasil posttest. Konseli MH adalah mahasiswa yang mempunyai masalah dalam pergaulan remaja (pacaran), sehingga mengganggu tugas akademiknya. Hal tersebut yang memicu konseli mengalami prokrastinasi akademik yang cukup tinggi. Namun setelah melakukan konseling kelompok dengan Teknik restructuring kongnitif, konseli sudah mampu dan mengetahui bagaimana cara membagi waktunya untuk belajar.

Konseli $\mathrm{AB}$ mendapatkan presentase skor pretest sebesar 85, kemudian diberikan treatment menggunakan teknik restructuring kognitif dalam konseling kelompok menurunkan tingkat prokrastinasi akademik menjadi 70 berdasarkan hasil posttest. Masalah dari konseli AB hamper sama dengan konseli FG yang berhubungan dengan game online. Konseli $\mathrm{AB}$ menomor satukan game online daripada mengerjakan tugas, sehingga tugas dari dosen seringkali terlupakan. Namun, setelah konseli FB melakukan konseling kelompok, dia mampu untuk menentukan prioritas yang harus dilakukan, yakni lebih memilih untuk mulai mengerjakan tugasnya lebih dahulu daripada bermain game online.

Budiyono (2019) menyatakan bahwa jika nilai 0.005 lebih kecil, maka Ha diterima. Berdasarkan hasil uji Wilcoxon pada tabel diatas diperoleh Asymp. Sig (2-tailed) adalah 0,005. Karena nilai 0,005 lebih kecil dari $<0,05$, dikatakan hipotesis Ha diterima, maka dapat disimpulkan bahwa teknik restrukturing kognitif dalam konseling kelompok berpengaruh terhadap prokrastinasi akademik mahasiswa bimbingan dan konseling Unipa Surabaya. Fajarudin dan Pratiwi (2016) berpendapat bahwa ketika konseli memikirkan hal negatif, maka hal negatif tersebut harus diubah menjadi hal positif, sehingga pelaksanaan restrukturing kognitif berjalan dengan baik dan lancar.

Dalam penelitiannya, peneliti menggunakan teknik restrukturing kognitif dalam konseling kelompok merupakan suatu pendekatan dimana tujuan atau goals sama dengan strategi restrukturing kognitif yaitu berfokus pada pengubahan atau mengkonstruk pemikiran irasional (negatif) menjadi pemirikan yang rasional (positif) dapat diterima oleh dirinya dan lingkungannya. Salah satu keberhasilan teknik restrukturing kognitif dalam konseling juga karena adanya faktor keinginan yang kuat dari subjek penelitian untuk menurunkan proktrastinasi akademiknya. Subjek penelitian berhasil memodifikasi disfungsional keyakinan dan tingkah lakunya. Keyakinan yang sebelumnya "Tugasnya dikerjakan nanti saja, saya mau bermain game dulu", menjadi "Sekarang harus saya mengerjakan tugasnya sekarang, kemudian saya main game". Pemikiran-pemikiran kecil seperti inilah yang dikembangkan dalam upaya penurunan prokrastinasi akademik. 


\section{KESIMPULAN}

Teknik restrukturing kognitif dalam konseling kelompok merupakan suatu pendekatan dimana tujuan atau goals sama dengan strategi restrukturing kognitif yaitu berfokus pada pengubahan atau mengkonstruk pemikiran irasional (pemikiran negatif) menjadi pemirikan yang rasional (positif) dapat diterima oleh dirinya dan lingkungannya. Pelaksanaan treatmen ini menggunakan aplikasi google meet karena masa pandemi covid-19 membatasi konselor dan konseli untuk bertatap muka secara langsung. Berdasarkan hasil uji Wilcoxon pada tabel diatas diperoleh Asymp. Sig (2-tailed) adalah 0.005. Karena nilai 0.005 lebih kecil dari $<0,05$, dikatakan hipotesis Ha diterima, maka dapat disimpulkan bahwa teknik restrukturing kognitif dalam konseling kelompok berpengaruh terhadap prokrastinasi akademik mahasiswa bimbingan dan konseling Unipa Surabaya.

\section{DAFTAR PUSTAKA}

Budiyono, A. (2019) 'Efektifitas Konseling Kelompok Berbasis Karakter Masyarakat Banyumas dalam Meningkatkan Sikap Asertif, KOMUNIKA: Jurnal Dakwah dan Komunikasi, 13(1), pp. 107-120. doi: 10.24090/komunika.v13i1.1926.

Edu, A. leo (2018) 'Jurnal Buana Pendidikan Tahun XIV, No. 25. Februari 2018', Buana Pendidikan, 14(25), pp. 14-20. Available at: http://jurnal.unipasby.ac.id/index.php/jurnal_buana_pendidikan/article/view/1452/1281.

Fajarudin, M. dan Pratiwi, T. (2016). Penerapan Strategi Cognotive Restructuring Untuk Menurunkan Persepsi Negatif Terhadap Pelaksanaan Program Bimbingan dan Konseling Pada Siswa Kelas X-4 SMA Negeri 1 Karangrejo Tulungagung. Jurnal BK UNES A 4., No. 2.

Hartono \& Soedarmadji, B. (2012). Psikologi konseling (Edisi Revisi). Jakarta: Kharisma Putra Utama.

Jannah, K., Suranata, K. and Suarni, N. K. (2019) 'Keefektifan konseling kognitif behavioral dengan teknik restrukturisasi kognitif untuk meningkatkan endurance siswa', Psychocentrum Review, 1(2), pp. 59-68. doi: $10.30998 /$ pcr.1279.

Pragholapati, A. (2020) 'Effect Of Progressive Muscle Relaxation Technique On Pain In Post Sectio caesarea', Jurnal Kesehatan dr. Soebandi, 8(2), pp. 112-122. doi: 10.36858/jkds.v8i2.216.

Rafikayati, A., Badiah, L. I. and Soedarmadji, B. (2018) 'Pengaruh Implementasi Layanan Bimbingan Pribadi Sosial Terhadap Penyesuaian Diri Anak Berkebutuhan Khusus (Abk) Di Sekolah Inklusif Sman 10 Surabaya', Buana Pendidikan: Jurnal Fakultas Keguruan dan Ilmu Pendidikan, 14(26), pp. 151-157. doi: 10.36456/bp.vol14.no26.a1680.

Saman, A. (2017) 'Analisis Prokrastinasi Akademik Mahasiswa (Studi Pada Mahasiswa Jurusan Psikologi Pendidikan Dan Bimbingan Fakultas Ilmu Pendidikan)', Jurnal Psikologi Pendidikan dan Konseling: Jurnal Kajian Psikologi Pendidikan dan Bimbingan Konseling, 3(2), p. 55. doi: 10.26858/jpkk.v0i0.3070.

Schraw, G., Olafson, L., \& Wadkins, T. (2007). Doing the things we do: A Grounded theory of academic procrastination. Journal of Educational Psychology, 99 (1), 12-25.

Sugiyono. (2017). Metode Penelitian Kuantitatif, Kualitatif, dan R\&DD. Bandung: CV. Alfabeta.

Suryabrata, Sumadi. (2014). Metodologi Penelitian Cetakan Ke 25. Jakarta: PT Rajagrafindo Persada.

Untari, S. K. (2020) 'Kreatifitas Guru Dalam Menyongsong Pembelajaran Masa Pandemi Covid- 19', Buana Pendidikan: Jurnal Fakultas Keguruan dan Ilmu Pendidikan, 16(30s), pp. 49-53. doi: 10.36456/bp.vol16.no30s.a2757. 